\title{
Resident satisfaction with the pediatric surgery training program
}

\author{
Tariq Altokhais ${ }^{1 *} \mathbb{D}$, Mohammed Al Rajhi ${ }^{2}$, Osama Bawazir ${ }^{3}$, Gassan T. Almogbel ${ }^{4}$, Abdullah I. Aljunaydil ${ }^{4}$ and \\ Abdullah Alshehri ${ }^{1}$
}

\begin{abstract}
Background: The pediatric surgery residency program is new in Saudi Arabia. As with any new program, residents experience a degree of fear and anxiety about their future in the program. The aim of this study is to examine residents' satisfaction with the program.

Methods: This study included an online survey examining residents' satisfaction. It consisted of demographic, financial, personality, program-specific, and burnout assessment questions. All questions were multiple-choice items. Descriptive statistical data are presented as frequency distributions and percentages. Cross-tabulations and chisquare tests were used at the bivariate level of analysis to compare subgroups and identify factors of satisfaction. Binary logistics regression was used at the multivariate level of analysis to compute the odds ratio of significant variables.

Results: Thirty-one out of 32 residents responded to the survey. The multivariate logistic regression showed that current year of residency, current relationship status and personality statistically affected the satisfaction of residents. Senior residents, i.e., residents who had spent four years or more in the program, were 40 times more likely to be satisfied than were residents in their first year; residents who were married were more than eight times more likely to be satisfied than were residents who were single; and residents who were neutral or who agreed that they were very indecisive were $8 \%$ less likely to be satisfied than were those who reported being decisive. Gender was statistically significant, such that males were more satisfied than females were.
\end{abstract}

Conclusions: Although the pediatric surgery residency program is new, this survey has shown that there is generally a high rate of satisfaction. Satisfaction was also observed more in senior residents. Further studies should be conducted in the future when residents graduate from the program.

Keywords: Pediatric, Surgery, Resident, Satisfaction

\section{Background}

Residency training programs are diverse in regard to many aspects, such as structure, workload, expectations, and experience. Some publications have examined residents' satisfaction and well-being in particular programs [1-3]. The pediatric surgery residency program is a six-

\footnotetext{
* Correspondence: taltokhais@ksu.edu.sa

'Division of pediatric surgery, Department of surgery, College of Medicine and King Saud University Medical City, King Saud University, P.O. Box: 1145111, Riyadh 4545, Saudi Arabia

Full list of author information is available at the end of the article
}

year structured program. The training is run according to a nation- wide curriculum approved by the Saudi Commission for Health Specialties (the only official governor training body in Saudi Arabia). The first residents entered the program in October 2016. The structure of the program is divided into three levels; core surgery level in the first and second years, junior pediatric surgery level in the third and fourth years, and senior pediatric surgery level in the fifth and sixth years. Currently, there are fourteen accredited training centers

(c) The Author(s). 2020 Open Access This article is licensed under a Creative Commons Attribution 4.0 International License, which permits use, sharing, adaptation, distribution and reproduction in any medium or format, as long as you give appropriate credit to the original author(s) and the source, provide a link to the Creative Commons licence, and indicate if changes were made. The images or other third party material in this article are included in the article's Creative Commons licence, unless indicated otherwise in a credit line to the material. If material is not included in the article's Creative Commons licence and your intended use is not permitted by statutory regulation or exceeds the permitted use, you will need to obtain permission directly from the copyright holder. To view a copy of this licence, visit http://creativecommons.org/licenses/by/4.0/ The Creative Commons Public Domain Dedication waiver (http://creativecommons.org/publicdomain/zero/1.0/) applies to the data made available in this article, unless otherwise stated in a credit line to the data. 
with 60 faculty distributed in Saudi Arabia. It is a joint program where residents rotate in different centers according to their level of training and according to the scope of service for each training center. Each center accepts a resident every other year. Annually, seven residents are accepted to enter the program. There were only two residents dropped out so far.

Different tools of assessment, formative and summative, are used based on the curriculum. These tools are logbook for surgical procedures, end of year written exam, structured oral exam, objective structured practical exam (OSPE), first part written exam, and final written and clinical exams.

The program is considered highly competitive in the Saudi Commission for Health Specialties matching system and is one of the top five programs since it started. More details of the program are available as a supplement and can be accessed at www.scfhs.org.sa.

The residents are relatively young which makes them vulnerable to burnout and with any new program, residents experience a degree of fear and anxiety about their future in the program [4]. The aim of this study is to examine residents' satisfaction with the program and the degree of burnout. To our knowledge, this is the first study of this program.

\section{Methods}

This study was approved by the Institutional Review Board. Project No. E-20-5007 and a written consent was obtained from the study participants. In April 2020, a voluntary online google documents survey was electronically distributed to all the residents in the training program using the list of registration at the Saudi Commission for Health Specialties for pediatric surgery program, Saudi Arabia. The online-based survey consisted of 15 demographic, financial, and personality questions, 20 program-specific questions, and 22 burnout assessment questions. All questions are multiplechoice items. The full survey is available as a supplement.

The data processing and analysis were performed using the Statistical Package for Social Sciences (SPSS) (Armonk, NY, USA, version 24). Descriptive statistical data are presented as frequency distributions and percentages. Cross-tabulations and chi-square tests were used at the bivariate level of analysis to compare subgroups and identify factors of satisfaction. Binary logistics regression was used at the multivariate level of analysis to compute the odds ratio of significant variables.

Satisfaction was measured by asking residents to select responses on a scale on which dissatisfaction is indicated if they chose "disagree" or "strongly disagree" and satisfaction if they chose "neutral", "agree", or "strongly agree".

For burnout questions, a dichotomous variable representing the satisfaction of residents was generated using all 22 items on the scale provided by the survey. A reliability test using Cronbach's alpha was conducted to measure the internal consistency of the items or questions. A Cronbach's alpha of $0.70(n=22)$ showed that the items have an accepted measure of internal consistency and can be used to generate a construct. Some questions were reversed to ensure that the responses from the questions were directional. The questions were thereafter compiled together. Respondents who had scores below 60 on the scale were categorized as satisfied, while respondents with scores above 60 on the scale were categorized as not satisfied.

\section{Results}

The program was composed of a total of 32 residents. Thirty-one (96.8\%) responded to the survey. Twentyeight residents were approximately equally distributed by postgraduate year (PGY), from PGY-1 to PGY-4. Only three residents were in PGY-5. Nineteen females and 12 males were aged between 25 and 30 years. Most of the residents were single (64.5\%). Half of the residents took care of other people similarly to how they would take care of their parents. Of those who took care of others, $4(26.7 \%)$ provided financial help, such that they sent money regularly to their parents; $3(20 \%)$ took care of their parents' social needs, such as accompanying them to their appointments or social events; and 8 (53.3\%) took care of both the financial and social needs of their parents. Most of the residents believed that their monthly salary was sufficient for basic requirements.

The bivariate analysis to determine the relationship between selected characteristics of the residents and satisfaction showed that there was a significant association between current year of residency and the satisfaction of residents $\left(\mathrm{X}^{2}(4, N=31)=9.83, p<.05\right)$. Residents who had spent 4 years or more in the program were satisfied more than were residents in their first year. Similarly, there was a significant association between gender and the satisfaction of residents $\left(\mathrm{X}^{2}(1, N=31)=4.29, p<.05\right)$ and between current relationship status and the satisfaction $\left(\mathrm{X}^{2}(1, N=31)=6.23, p<.05\right)$. The percentages of respondents who were satisfied or not did not differ significantly across all other variables (Table 1 ).

The bivariate analysis to determine the relationship between personality and the satisfaction of residents showed that there was a significant association between people who are indecisive and satisfaction $\left(\mathrm{X}^{2}(1, N=\right.$ $31)=7.89, p<.05)$. Satisfaction did not differ among those with other personality types (Table 2 ). 
Table 1 Bivariate Analysis of Socio-Demographic variables on Satisfaction of Residents

\begin{tabular}{|c|c|c|c|c|c|}
\hline VARIABLE & $\begin{array}{l}\text { Satisfied } \\
\text { (\%) }\end{array}$ & Not Satisfied (\%) & $\begin{array}{l}\text { Total } \\
(\%)\end{array}$ & Chi-Square & $p$-value \\
\hline \multicolumn{6}{|c|}{ What is your current Residency year? } \\
\hline \multirow[t]{2}{*}{1} & 2 & 6 & 8 & 9.83 & 0.043 \\
\hline & $25.00 \%$ & $75.00 \%$ & $100.00 \%$ & & \\
\hline \multirow[t]{2}{*}{2} & 3 & 3 & 6 & & \\
\hline & $50.00 \%$ & $50.00 \%$ & $100.00 \%$ & & \\
\hline \multirow[t]{2}{*}{3} & 2 & 5 & 7 & & \\
\hline & $28.60 \%$ & $71.40 \%$ & $100.00 \%$ & & \\
\hline \multirow[t]{2}{*}{4} & 6 & 1 & 7 & & \\
\hline & $85.70 \%$ & $14.30 \%$ & $100.00 \%$ & & \\
\hline \multirow[t]{2}{*}{5} & 3 & 0 & 3 & & \\
\hline & $100.00 \%$ & $0.00 \%$ & $100.00 \%$ & & \\
\hline \multicolumn{6}{|l|}{ Gender } \\
\hline \multirow[t]{2}{*}{ Male } & 9 & 3 & 12 & 4.29 & 0.038 \\
\hline & $75.00 \%$ & $25.00 \%$ & $100.00 \%$ & & \\
\hline \multirow[t]{2}{*}{ Female } & 7 & 12 & 19 & & \\
\hline & $36.80 \%$ & $63.20 \%$ & $100.00 \%$ & & \\
\hline \multicolumn{6}{|c|}{ Current relationship status } \\
\hline \multirow[t]{2}{*}{ Single } & 7 & 13 & 20 & 6.23 & 0.013 \\
\hline & $35.00 \%$ & $65.00 \%$ & $100.00 \%$ & & \\
\hline \multirow[t]{2}{*}{ Married } & 9 & 2 & 11 & & \\
\hline & $81.80 \%$ & $18.20 \%$ & $100.00 \%$ & & \\
\hline \multicolumn{6}{|c|}{ If you are married, does your spouse also work in a healthcare field? } \\
\hline \multirow[t]{2}{*}{ Yes } & 3 & 2 & 5 & 1.59 & 0.207 \\
\hline & $60.00 \%$ & $40.00 \%$ & $100.00 \%$ & & \\
\hline \multirow[t]{2}{*}{ No } & 8 & 1 & 9 & & \\
\hline & $88.90 \%$ & $11.10 \%$ & $100.00 \%$ & & \\
\hline \multicolumn{6}{|l|}{ Number of kids } \\
\hline \multirow[t]{2}{*}{0} & 7 & 5 & 12 & 2.95 & 0.229 \\
\hline & $58.30 \%$ & $41.70 \%$ & $100.00 \%$ & & \\
\hline \multirow[t]{2}{*}{1} & 4 & 0 & 4 & & \\
\hline & $100.00 \%$ & $0.00 \%$ & $100.00 \%$ & & \\
\hline \multirow[t]{2}{*}{2} & 1 & 0 & 1 & & \\
\hline & $100.00 \%$ & $0.00 \%$ & $100.00 \%$ & & \\
\hline \multicolumn{6}{|c|}{ Do you take care of others; like parents? } \\
\hline \multirow[t]{2}{*}{ Yes } & 10 & 4 & 14 & 0.76 & 0.383 \\
\hline & $71.40 \%$ & $28.60 \%$ & $100.00 \%$ & & \\
\hline \multirow[t]{2}{*}{ No } & 6 & 5 & 11 & & \\
\hline & $54.50 \%$ & $45.50 \%$ & $100.00 \%$ & & \\
\hline \multicolumn{6}{|c|}{ Monthly salary (Saudi Riyal): } \\
\hline \multirow[t]{2}{*}{ Less than 20,000} & 11 & 10 & 21 & 0.02 & 0.901 \\
\hline & $52.40 \%$ & $47.60 \%$ & $100.00 \%$ & & \\
\hline $20,000-30,000$ & 5 & 5 & 10 & & \\
\hline & $50.00 \%$ & $50.00 \%$ & $100.00 \%$ & & \\
\hline
\end{tabular}

The bivariate analysis to determine the relationship between faculty or program characteristics and the satisfaction of residents showed that satisfaction did not differ at the $95 \%$ confidence interval with respect to faculty or program characteristics (Table 3 ). The residents rotate in different core rotations. They were asked about 
Table 2 Bivariate Analysis of Personality on Satisfaction of Residents

\begin{tabular}{|c|c|c|c|c|c|}
\hline Variable & $\begin{array}{l}\text { Satisfied } \\
(\%)\end{array}$ & Not Satisfied (\%) & $\begin{array}{l}\text { Total } \\
\text { (\%) }\end{array}$ & Chi Square & $p$-value \\
\hline \multicolumn{6}{|c|}{ I would describe myself as a perfectionist } \\
\hline \multirow[t]{2}{*}{ Disagree } & 1 & 2 & 3 & 0.44 & 0.505 \\
\hline & $33.30 \%$ & $66.70 \%$ & $100.00 \%$ & & \\
\hline \multirow[t]{2}{*}{ Agree or Neutral } & 15 & 13 & 28 & & \\
\hline & $53.60 \%$ & $46.40 \%$ & $100.00 \%$ & & \\
\hline \multicolumn{6}{|c|}{ I would describe myself as very empathetic } \\
\hline \multirow[t]{2}{*}{ Disagree } & 1 & 2 & 3 & 0.44 & 0.505 \\
\hline & $33.30 \%$ & $66.70 \%$ & $100.00 \%$ & & \\
\hline \multirow[t]{2}{*}{ Agree or Neutral } & 15 & 13 & 28 & & \\
\hline & $53.60 \%$ & $46.40 \%$ & $100.00 \%$ & & \\
\hline \multicolumn{6}{|c|}{ I would describe myself as very indecisive } \\
\hline \multirow[t]{2}{*}{ Disagree } & 10 & 2 & 12 & 7.89 & 0.005 \\
\hline & $83.30 \%$ & $16.70 \%$ & $100.00 \%$ & & \\
\hline \multirow[t]{2}{*}{ Agree or Neutral } & 6 & 13 & 19 & & \\
\hline & $31.60 \%$ & $68.40 \%$ & $100.00 \%$ & & \\
\hline \multicolumn{6}{|c|}{ I would describe myself as very idealistic } \\
\hline \multirow[t]{2}{*}{ Disagree } & 3 & 1 & 4 & 1.01 & 0.316 \\
\hline & $75.00 \%$ & $25.00 \%$ & $100.00 \%$ & & \\
\hline \multirow[t]{2}{*}{ Agree or Neutral } & 13 & 14 & 27 & & \\
\hline & $48.10 \%$ & $51.90 \%$ & $100.00 \%$ & & \\
\hline
\end{tabular}

their satisfaction in those rotations. All rotations were satisfactory except the plastic surgery rotation (Fig. 1).

For burnout, 22 questions were asked, and the results showed that 16 (51.6\%) respondents were satisfied, while 15 (48.4\%) respondents were not satisfied.

The multivariate logistic regression to determine the factors affecting the satisfaction of residents showed that their current year of residency, current relationship status, personality statistically, and gender affect their satisfaction. Senior residents, i.e., residents who had spent 4 years or more in the program, were 40 times more likely to be satisfied than were residents in their first year $($ O.R. $=40.160, p<.05)$; residents who were married were more than eight times more likely to be satisfied than were residents who were single $(\mathrm{O} . \mathrm{R} .=8.36, p<.05)$; and residents who were neutral or who considered themselves to be very indecisive were $8 \%$ less likely to be satisfied than were residents who reported being decisive (O.R. $=5.14, p<.05)$. Gender was statistically significant, such that males were more satisfied than females were (Table 4).

\section{Discussion}

The pediatric surgery training program is new in Saudi Arabia. With any new program, anxiety and many other concerns may arise regarding the program and the future of the gradates. We conducted this survey 4 years after the beginning of the program to examine and explore residents' satisfaction with the program. Resident satisfaction is an important performance metric for surgery programs. Low satisfaction can lead to resident attrition [3]. Increased satisfaction potentially improves the performance, productivity, and retention of residents [3-7].

From the survey, there was a significant association between current year of residency and the satisfaction of residents, where satisfaction improved significantly when they became seniors. The more senior the resident, the more satisfied they were. Senior residents, i.e., residents who had spent 4 years or more in the program, were 40 times more likely to be satisfied than were residents in their first year. This finding could be explained by the fact that residents learned more as they progressed through the program, or may be due to the many rotations they have to go through during their more junior years, which may in turn affect their satisfaction.

There was a significant association between gender and the satisfaction of residents, and there was a statistically significant association between current relationship status and satisfaction. Single female residents were less satisfied with the program than were males or married residents. 
Table 3 Bivariate Analysis of Faculty/Program Characteristics on Satisfaction of Residents

\begin{tabular}{|c|c|c|c|c|c|}
\hline Variable & $\begin{array}{l}\text { Satisfied } \\
\text { (\%) }\end{array}$ & Not Satisfied (\%) & $\begin{array}{l}\text { Total } \\
(\%)\end{array}$ & Chi Square & $p$-value \\
\hline \multicolumn{6}{|c|}{ Faculty and staff in my program care about my educational success. } \\
\hline \multirow[t]{2}{*}{ Disagree } & 0 & 1 & 1 & 1.10 & 0.294 \\
\hline & $0.00 \%$ & $100.00 \%$ & $100.00 \%$ & & \\
\hline \multirow[t]{2}{*}{ Agree or Neutral } & 16 & 14 & 30 & & \\
\hline & $53.30 \%$ & $46.70 \%$ & $100.00 \%$ & & \\
\hline \multicolumn{6}{|c|}{ My program uses resident feedback constructively. } \\
\hline \multirow[t]{2}{*}{ Disagree } & 5 & 1 & 6 & 3.00 & 0.083 \\
\hline & $83.30 \%$ & $16.70 \%$ & $100.00 \%$ & & \\
\hline \multirow[t]{2}{*}{ Agree or Neutral } & 11 & 14 & 25 & & \\
\hline & $44.00 \%$ & $56.00 \%$ & $100.00 \%$ & & \\
\hline
\end{tabular}

I am able to have an adequate balance between work and personal life.

$\begin{array}{lllll}\text { Disagree } & 4 & 6 & 10 & 0.80 \\ \text { Agree or Neutral } & 40.00 \% & 60.00 \% & 100.00 \% & 21 \\ & 12 & 9 & 100.00 \%\end{array}$

I often have a workload that results significant stress.

$\begin{array}{lllll}\text { Disagree } & 2 & 0 & 2 & 2.00 \\ & 100.00 \% & 0.00 \% & 100.00 \% & 29 \\ \text { Agree or Neutral } & 14 & 15 & 100.00 \%\end{array}$

I would choose the same pediatric surgery residency program again if I had the chance.

$\begin{array}{lllll}\text { Disagree } & 0 & 1 & 1 & 1.10 \\ \text { Agree or Neutral } & 0.00 \% & 100.00 \% & 100.00 \% & 30 \\ & 16 & 14 & 100.00 \%\end{array}$

I feel there is a lot of ambiguity and vagueness in the program.

$\begin{array}{llllll}\text { Disagree } & 4 & 6 & 10 & 0.372 \\ & 40.00 \% & 60.00 \% & 100.00 \% & 21 \\ \text { Agree or Neutral } & 12 & 9 & 100.00 \%\end{array}$

I am afraid about the future after graduation from the program in terms of: I feel I will not have enough knowledge of pediatric surgery.

$\begin{array}{lllll}\text { Disagree } & 11 & 7 & 18 & 1.55 \\ \text { Agree or Neutral } & 61.10 \% & 38.90 \% & 100.00 \% & 13 \\ & 5 & 8 & 100.00 \%\end{array}$

I am afraid about the future after graduation from the program in terms of: I feel I will not have enough surgical skills.

$\begin{array}{llllll}\text { Disagree } & 4 & 6 & 10 & 0.372 \\ \text { Agree or Neutral } & 40.00 \% & 60.00 \% & 100.00 \% & 21 \\ & 12 & 9 & 100.00 \%\end{array}$

I am afraid about the future after graduation from the program in terms of: I feel I will not be accepted/employed in any respectful Hospital/institution.
Disagree
6
5
11
0.06
0.809
Agree or Neutral
$54.50 \% \quad 45.50 \%$
$100.00 \%$
$10 \quad 10 \quad 20$
$50.00 \%$
$50.00 \% \quad 100.00 \%$ 


\section{Satisfaction with core rotations}

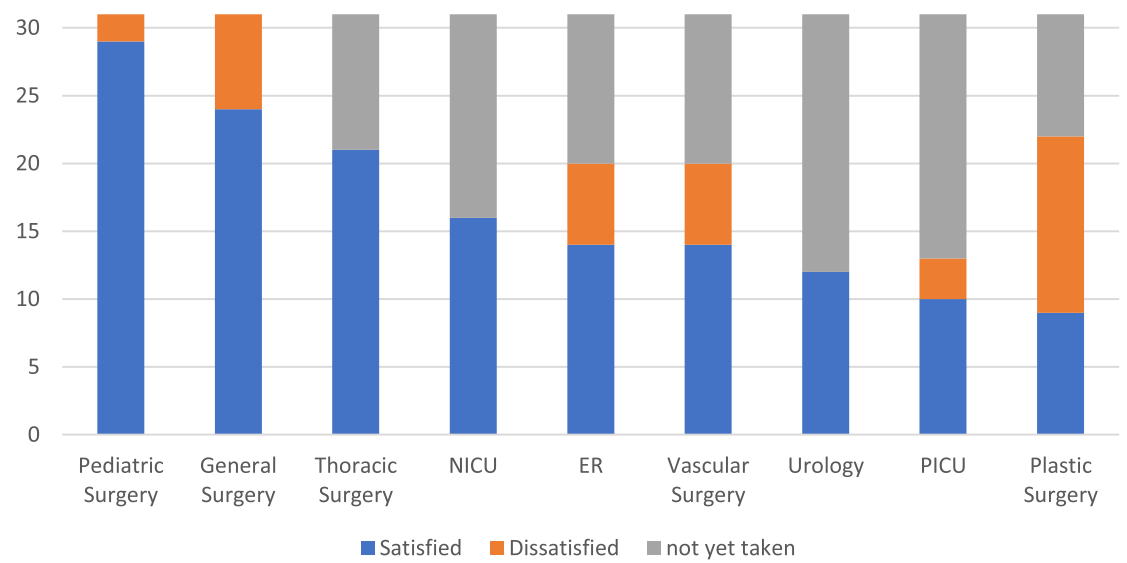

NICU, neonatal intensive care unit; ER, emergency unit; PICU, pediatric intensive care unit.

Fig. 1 Satisfaction with core rotations. NICU, neonatal intensive care unit; ER, emergency unit; PICU, pediatric intensive care unit

Demographic and socioeconomic factors have been reported as reasons for dissatisfaction in the literature [8], but in this survey, these factors were not related to differences in satisfaction.

Most of the residents were satisfied with the program structure, faculty, and different rotations. All of the residents except one would choose the same pediatric surgery training program if they had the chance.

The survey contained 22 questions about burnout. Although most residents were satisfied with the program

Table 4 Multivariate Logistics Regression; Satisfaction of Residents

\begin{tabular}{|c|c|c|c|}
\hline Variable & p-value & Odds Ratio & 95\% Confidence Interval \\
\hline \multicolumn{4}{|c|}{ What is your current Residency year? } \\
\hline 1 & $\mathrm{RC}$ & & \\
\hline 2 & .341 & 3.00 & $0.312-28.841$ \\
\hline 3 & .876 & 1.20 & $0.121-11.865$ \\
\hline 4 & .033 & 18.00 & $1.267-255.744$ \\
\hline 5 & .999 & $484^{e 5}$ & - \\
\hline \multicolumn{4}{|l|}{ Gender } \\
\hline Female & $\mathrm{RC}$ & & \\
\hline Male & .046 & 5.143 & $1.033-25.602$ \\
\hline \multicolumn{4}{|c|}{ Current Relationship Status } \\
\hline Single & $\mathrm{RC}$ & & \\
\hline Married & .020 & 8.357 & $1.400-49.883$ \\
\hline \multicolumn{4}{|c|}{ I would describe myself as very indecisive } \\
\hline Disagree & $\mathrm{RC}$ & & \\
\hline Agree or Neutral & .009 & 0.092 & $0.015-0.559$ \\
\hline
\end{tabular}

in general, half of them were dissatisfied when answering burnout questions. Burnout is experienced as emotional exhaustion or depersonalization $[9,10]$. A recent study showed a burnout rate of $43.9 \%$ among physicians in the United States [11]. Burnout may lead to physical and emotional withdrawal, which may adversely affect patient care [11].

Training program satisfaction surveys may guide to implement interventions that improve satisfaction and reduce burnout [1]. Using residents' feedback constructively and controlling the work load improve the program. The survey may help to address certain potential areas in the program that needs to be improved and lead to increase residents' satisfaction. Although the curriculum for the program is regularly updated, findings from this survey maybe considered in the updates to reflect residents' opinion and feedback.

This survey had some limitations. Although the response rate was $96.8 \%$, the total number of residents was small. In addition, the survey might have produced different results if it had been distributed after a few years, when some residents had graduated from the program.

\section{Conclusion}

Although the pediatric surgery residency program is new, this survey has shown that there is generally a high rate of satisfaction. Satisfaction was also observed more in senior residents. Further studies should be conducted in the future when residents graduate from the program.

Abbreviations

PGY: Postgraduate year 


\section{Acknowledgements}

Not applicable.

\section{Authors' contributions}

TA: Idea, Creation of questionnaire, Manuscript writing. MA: Creation of questionnaire. OB: Creation of questionnaire. GA: Data collection, Data analysis. AIA: Data collection, Data analysis. AA: Manuscript writing. All authors have read and approved the manuscript.

\section{Funding}

This research did not receive any specific grant from funding agencies in the public, commercial, or not-for-profit sectors.

\section{Availability of data and materials}

All data used in the study are available to be reviewed.

\section{Ethics approval and consent to participate}

This study was approved by King Saud University, College of Medicine Institutional Review Board. Project No. E-20-5007. All participants have signed a written consent prior to participate in the study.

\section{Consent for publication}

N/A

\section{Competing interests}

Authors of the study do not have any conflict of interest in the study.

\section{Author details}

'Division of pediatric surgery, Department of surgery, College of Medicine and King Saud University Medical City, King Saud University, P.O. Box: 1145111, Riyadh 4545, Saudi Arabia. ${ }^{2}$ Division of pediatric surgery, Security Forces Hospital, Riyadh, Saudi Arabia. ${ }^{3}$ Department of Surgery, Faculty of Medicine, Umm Al-Qura University, Makkah, Saudi Arabia. ${ }^{4}$ College of Medicine and King Saud University Medical City, King Saud University, Riyadh, Saudi Arabia.

Received: 8 July 2020 Accepted: 14 October 2020

Published online: 20 October 2020

\section{References}

1. Ahmad AA, Ramey SJ, Dean MK, Yoo SK, Holliday E, Deville C, , Takita C, Vapiwala N, Wilson LD, Jagsi R, Thomas CR Jr, Yechieli R. Resident satisfaction with radiation oncology training. Adv Radiat Oncol 2018;20(3): 234-239. https://doi.org/https://doi.org/10.1016/j.adro.2018.03.003.

2. Dansey K, Wooster M, Shames M. Integrated vascular surgery resident satisfaction. Ann Vasc Surg 2015;29(8):1581-1588. https://doi.org/https://doi. org/10.1016/j.avsg.2015.05.033.

3. Perone JA, Fankhauser GT, Adhikari D, Mehta HB, Woods MB, Tyler DS, Brown KM. It depends on your perspective: resident satisfaction with operative experience. Am J Surg 2017;213(2):253-259. https://doi.org/ https://doi.org/10.1016/j.amjsurg.2016.09.042.

4. Prins JT, Gazendam-Donofrio SM, Tubben BJ, van der Heijden FM, van de Wiel HB, Hoekstra-Weebers JE. Burnout in medical residents: a review. Med Educ. 2007;41(8):788-800. https://doi.org/10.1111/j.1365-2923.2007.02797.

5. Judge TA, Bono JE. Relationship of core self-evaluations traits-self-esteem, generalized self-efficacy, locus of control, and emotional stability - with job satisfaction and job performance: a meta-analysis. J Appl Psychol 2001;86: 80-92. https://doi.org/https://doi.org/10.1037/0021-9010.86.1.80.

6. Judge TA, Thoresen CJ, Bono JE, Patton GK. The job satisfaction-job performance relationship: a qualitative and quantitative review. Psychol Bull 2001;127:376-407. https://doi.org/https://doi.org/10.1037/0033-2909.127.3.376.

7. Maslach C, Jackson S. The measurement of experienced burnout. J Occup Behav. 1981;2:99-113 https://www.jstor.org/stable/3000281.

8. Oslon K, Sinsky C, Rinne ST, Long T, Vender R, Mukherjee S, Bennick M, Linzer M. Cross-sectional survey of workplace stressors associated with physician burnout measured by the mini-Z and Maslach burnout inventory. Stress Health 2019;35(2):157-175. https://doi.org/https://doi.org/10.1002/smi. 2849.

9. Shanafelt TD, Hasan O, Dyrbye LN, Sinsky C, Satele D, Sloan J, West CP. Changes in burnout and satisfaction with work-life balance in physicians and the general US working population between 2011 and 2014. Mayo Clin
Proc 2015;90(12):1600-1613. https://doi.org/https://doi.org/10.1016/j. mayocp.2015.08.023.

10. Noseworthy J, Madara J, Cosgrove D, Edgeworth M, Ellison E, Krevans S, Rothman P, Sowers K, Strongwater S, Torchiana DF, Harrison D. Physician burnout is a public health crisis. A massage to our fellow healthcare CEO's. Health Affairs. 2017. https://www.healthaffairs.org/do/https://doi.org/10. 1377/hblog20170328.059397/full/.

11. Khan JS, Witteles RM, Mahaffey KW, Desai SA, Ozdalga E, Heidenreich PA. A 15-year review of the Stanford internal medicine residency program: predictors of resident satisfaction and dissatisfaction. Adv Med Educ Prac 2017;2(8):559-566. https://doi.org/https://doi.org/10.2147/AMEP.S138467.

\section{Publisher's Note}

Springer Nature remains neutral with regard to jurisdictional claims in published maps and institutional affiliations.
Ready to submit your research? Choose BMC and benefit from:

- fast, convenient online submission

- thorough peer review by experienced researchers in your field

- rapid publication on acceptance

- support for research data, including large and complex data types

- gold Open Access which fosters wider collaboration and increased citations

- maximum visibility for your research: over $100 \mathrm{M}$ website views per year

At BMC, research is always in progress.

Learn more biomedcentral.com/submissions 